\title{
Evaluation of primary health workers training program to provide psychoeducation to family caregivers of persons with psychotic disorder
}

\author{
Carla Raymondalexas Marchira ${ }^{1 *}$, Warih Andan Puspitasari², Ida Rochmawati ${ }^{3}$, \\ Siti Mulyani ${ }^{4}$ \\ ${ }^{1}$ Department of Psychiatry Faculty of Medicine Universitas Gadjah Mada, ${ }^{2}$ Department \\ of Psychiatry Faculty of Medicine and Health Sciences Universitas Muhammadiyah \\ Yogyakarta, ${ }^{3}$ Wonosari Hospital, Gunung Kidul, Yogyakarta, ${ }^{4}$ Kasihan 2 Primary Health \\ Center, Bantul, Yogyakarta, Indonesia
}

DOI: http://dx.doi.org/10.19106/JMedSci004701201505

\section{ABTRACT}

Many persons suffering psychotic illnesses, such as schizophrenia, are largely untreated in low income countries. In these settings, most persons with severe mental illness live with their families. Thus, families play a particular critical role in determining whether a person with a psychotic illness will receive treatment and what the quality of treatment. Psychoeducation has proven to be extremely effective in helping families develop the knowledge and skills which is necessary to help their family members. Indonesia has a national policy to integrate the management of mental health problems into the primary health care system. However, in practice, such care does not implemented effectively. A preliminary study in primary health centers in two districts of Bantul and Gunung Kidul regency, Yogyakarta province, showed that there was very little or there is not any training for health care workers on diagnosis and treatment of psychotic disorder. This study was conducted to evaluate the effectiveness of the training program for health workers in three primary health centers in Yogyakarta, Indonesia, to provide psychoeducation to family caregivers for persons with psychotic disorder. A quasi-experimental study with the approach of one group pre and posttest design was performed in this study. Fortythree health workers in 3 primary health centers in Bantul and Gunung Kidul, Yogyakarta were trained every week for a month to provide psychoeducation to family caregivers who live with psychotic disorder patient. Result showed that the baseline score of knowledge of schizophrenia among health workers in 3 primary health centers in Bantul and Gunung Kidul before training were not significantly different $(p=0.162)$. After the psychoeducation training program there were significantly different $(p=0.003)$ of the score of knowledge of schizophrenia among health workers in 3 primary health care centers compared with before training. For conclusion, the training program to provide psychoeducation to family care providers of persons with psychotic disorder for primary health workers was effective to increase their knowledge of schizophrenia.

\section{ABSTRAK}

Banyak penderita gangguan psikosis, seperti skizofrenia, yang tidak mendapatkan pengobatan di negara-negara dengan penghasilan perkapita rendah. Pada situasi seperti

\footnotetext{
* corresponding author: carlamarchira@yahoo.com
} 
Carla R. Marchira et al., Evaluation of primary health workers training program to provide psychoeducation to family caregivers of persons with psychotic disorder

ini, kebanyakan orang dengan gangguan mental yang berat hidup dengan keluarga mereka. Keluarga dalam hal ini memainkan peran yang sangat penting dalam menentukan apakah seseorang dengan gangguan psikosis akan menerima perawatan dan bagaimana kualitas pengobatan yang didapatkan. Psikoedukasi telah terbukti sangat efektif dalam membantu keluarga mengembangkan pengetahuan dan keterampilan yang diperlukan untuk membantu anggota keluarga mereka yang menderita gangguan mental. Indonesia memiliki kebijakan nasional mengintegrasikan pengelolaan masalah kesehatan mental ke dalam sistem pelayanan kesehatan dasar. Namun dalam praktiknya, hal tersebut tidak dilaksanakan secara efektif. Studi pendahuluan di pusat kesehatan masyarakat (Puskesmas) di dua kabupaten yaitu Bantul dan Gunung Kidul, Yogyakarta, menunjukkan bahwa sangat sedikit atau bahkan tidak ada pelatihan bagi tenaga kesehatan di layanan primer untuk melakukan diagnosis dan pengobatan gangguan psikosis. Penelitian ini bertujuan untuk mengevaluasi efektivitas program pelatihan bagi tenaga kesehatan di tiga Puskesmas di Yogyakarta, Indonesia, untuk memberikan psikoedukasi bagi keluarga dengan penderita gangguan psikosis. Desain penelitian ini adalah eksperimen kuasi dengan pendekatan one group pre and posttest. Empat puluh tiga petugas kesehatan di 3 Puskesmas di Bantul dan Gunung Kidul, Yogyakarta dilatih setiap minggu selama satu bulan yang memberikan psikoedukasi untuk keluarga yang tinggal dengan penderita gangguan psikosis. Hasil penelitian menunjukkan bahwa rata-rata skor pengetahuan skizofrenia antara petugas kesehatan di 3 puskesmas di Bantul dan Gunung Kidul sebelum pelatihan, tidak terdapat perbedaan yang signifikan ( $p$ $=0.162$ ). Setelah dilakukan program pelatihan psikoedukasi, skor pengetahuan skizofrenia petugas kesehatan di 3 puskesmas berbeda secara signifikan $(p=0,003)$ dibandingkan sebelum pelatihan. Sebagai kesimpulan, program pelatihan untuk memberikan psikoedukasi bagi keluarga dengan penderita gangguan psikosis bagi tenaga kesehatan di layanan primer efektif untuk meningkatkan pengetahuan mereka tentang skizofrenia.

Keywords: training - psychoeducation - primary health center - health workers - psychotic disorder

\section{INTRODUCTION}

Mental disorders become the greatest burden of the disease as measured by DALYs (disability-adjusted life years), included psychotic disorder. ${ }^{1}$ Schizophrenia is the most psychotic disorder that is characterized by chronic cycles of remission and relapse and require long-term management. ${ }^{2-4}$ Giving antipsychotics accompanied by supporting management, will provide more optimal results in improving the quality of life of patients. In the management of psychotic patients, quality of life is more important than patients' recovery. ${ }^{5}$ However, there are many patients did not get effective treatment. ${ }^{6}$ Lack of facilities and resources in mental health care, make the burden of schizophrenia patient care is imposed on their families.
Families are the main factors that influence the success of therapy, as most patients live and cared by their families. According to Sudiyanto, the ability to identify the needs of person with schizophrenia is very limited, so that families have the most responsibility to protect, preserve and maintain the schizophrenia treatment. ${ }^{7}$ Families play a very important role in determining whether patients receive treatment and how the quality of treatment provided, including compliance with medication. ${ }^{7}$ However, families often do not have enough knowledge about the disorder and treatment needed to achieve a good quality of life for patients with psychotic disorder. Based on the Patient Outcomes Research Team's (PORT) record, failure of therapy of schizophrenia patient with families 
who received health education $10 \%$ only, so that it is needed to increase knowledge and understanding the families in treating schizophrenia patients properly. ${ }^{8}$

Psychoeducation has been shown very effective in helping families develop the knowledge and skills necessary to help their family members. Family psychoeducation aims to provide support, information and education to families. ${ }^{9}$ Their conclude that family psychoeducation can be effective, especially to reduce the relapse of patients with schizophrenia. Indonesia has a national policy to integrate the management of mental health problems in the primary health care system. However, in practice, these treatments have not implemented effectively..$^{10}$ A preliminary study in primary health centers in two regencies of Bantul and Gunung Kidul, Yogyakarta province, showed that there was very little or there was not any training for health workers on the diagnosis and treatment of psychotic disorder, including the training of psychoeducation in schizophrenia disorder. ${ }^{11,12}$

To meet the needs of health professionals to increase the knowledge and skills of psychoeducation, district health office and the Department of Psychiatry Faculty of Medicine Universitas Gadjah Mada conducted training programs for health workers in primary health centers. After the training, the health workers will be able to involve the community and families in the management of psychotic disorders. Furthermore, health workers are expected to provide psychoeducation training to the families with psychotic disorders patients in the region. The aim of this research was to evaluate the effectiveness of a formal training program designed to train health workers in primary health centers to provide psychoeducation to families with psychotic disorders.

\section{MATERIALS AND METHODS}

This study used a quasi-experimental study design with the approach of one group pre-posttest design which measurements were performed at baseline and at the end of the study. ${ }^{13}$ The subjects in this study were health workers in Kasihan 2 and Dlingo 1 primary health centers, in Bantul regency, and Wonosari 2 primary health center, in Gunung Kidul regency. Health workers were trained every week for a month aimed to prepare them to provide psychoeducation to family caregivers of persons who live with psychotic disorder. Training was conducted in 4 sessions, each session lasting one to two hours, contains the knowledge about schizophrenia, using brief interactive psychoeducation module about schizophrenia. ${ }^{11,12,14,15}$ Each session describes the definition and causes, symptoms, treatment, and support systems, service and introduction of increased symptoms of schizophrenia. We measured the Knowledge of Schizophrenia (KOS), which consisted of 18 items of questions, before and after the psychoeducation training.14-16 This study was conducted in December 2013-March 2014.

\section{RESULTS}

The psychoeducation training was conducted to health workers at three primary health centers in two districts in Yogyakarta province, i.e Dlingo 1, Kasihan 2 and Wonosari 2. A total of 43 health workers, 12 health workers from Kasihan 2, 12 from Dlingo 1 and 19 from Wonosari 2 primary health center completed the full psychoeducation training. Profile of health workers in primary health centers can be seen in TABLE 1 . 
Carla R. Marchira et al., Evaluation of primary health workers training program to provide psychoeducation to family caregivers of persons with psychotic disorder

TABLE 1. Profile of health workers in primary health centers

\begin{tabular}{lcccccc}
\hline \multirow{2}{*}{ Primary Health Center } & \multicolumn{3}{c}{ Sex } & \multicolumn{2}{c}{ Position } \\
\cline { 2 - 7 } & Female & Male & Medical Doctor & Nurse & Midwife & Others \\
\hline Kasihan 2 & 9 & 3 & 2 & 5 & 1 & 4 \\
\hline Wonosari 2 & 13 & 6 & 2 & 9 & 6 & 2 \\
\hline Dlingo 1 & 5 & 7 & 3 & 3 & 1 & 5 \\
\hline Total & 27 & 16 & 7 & 17 & 8 & 11 \\
\hline
\end{tabular}

Source: primary data

TABLE 2 shows the percentage of correct answers of Knowledge of Schizophrenia health center and the increase of correct (KOS) at pretest and posttest in each primary answers.

TABLE 2. Percentage of the correct answer of Knowledge of Schizophrenia (KOS) on health workers in 3 primary health centers

\begin{tabular}{lccc}
\hline Primary Health Centers & $\begin{array}{c}\text { Pretest } \\
(\%)\end{array}$ & $\begin{array}{c}\text { Posttest } \\
(\%)\end{array}$ & $\begin{array}{c}\text { Increase } \\
(\%)\end{array}$ \\
\hline Kasihan 2 & 51.85 & 88.42 & 36.57 \\
\hline Wonosari 2 & 54.68 & 74.85 & 20.17 \\
\hline Dlingo 1 & 61.57 & 74.1 & 12.53 \\
\hline Mean & & & 23.09 \\
\hline
\end{tabular}

Source: primary data

TABLE 3 shows the mean difference of pretest and posttest scores of KOS in health workers at 3 primary health centers. There were not any differences in baseline KOS scores at the pretest of 3 primary health centers $(\mathrm{p}=0.162)$. There was a significant difference at the posttest $(\mathrm{p}=0.003)$.

TABLE 3. The mean difference of pretest and posttest scores of Knowledge of Schizophrenia (KOS) in health workers in 3 primary health centers

\begin{tabular}{|c|c|c|c|c|c|c|}
\hline $\begin{array}{c}\text { Primary } \\
\text { Health Center }\end{array}$ & $\mathrm{N}$ & Mean \pm SD & $\begin{array}{c}95 \% \mathrm{CI} \text { for } \\
\text { mean }\end{array}$ & Minimum & Maximum & $\mathrm{p}$ \\
\hline \multicolumn{7}{|l|}{ KOS 1} \\
\hline Dlingo & 12 & $11.08 \pm 3.029$ & $9.16 \pm 13.01$ & 6 & 16 & \multirow{3}{*}{0.162} \\
\hline Wonosari & 19 & $9.84 \pm 2.141$ & $8.81 \pm 10.87$ & 7 & 14 & \\
\hline Kasihan & 12 & $9.33 \pm 1.497$ & $8.38 \pm 10.28$ & 6 & 12 & \\
\hline \multicolumn{7}{|l|}{ KOS 2} \\
\hline Dlingo & 12 & $13.33 \pm 2.188$ & $11.94 \pm 14.72$ & 9 & 16 & \multirow{3}{*}{0.003} \\
\hline Wonosari & 19 & $13.47 \pm 1.867$ & $12.57 \pm 14.37$ & 9 & 17 & \\
\hline Kasihan & 12 & $15.92 \pm 2.021$ & $14.63 \pm 17.20$ & 11 & 18 & \\
\hline
\end{tabular}

Source: primary data 
TABLE 4 shows the mean difference between the delta KOS on health workers in 3 primary health centers. There were significant difference in the mean delta KOS between 3 primary health centers $(\mathrm{p}=0.001)$.

TABLE 4. The mean difference between the delta Knowledge of Schizophrenia (KOS) on health workers in 3 primary health centers.

\begin{tabular}{lcccccc}
\hline $\begin{array}{l}\text { Primary Health } \\
\text { Center }\end{array}$ & $\mathrm{N}$ & Mean & $\begin{array}{c}\text { 95\% CI for } \\
\text { Mean }\end{array}$ & Minimum & Maximum & $\mathrm{p}$ \\
\cline { 1 - 5 } Dlingo & 12 & $2.25 \pm 2.701$ & $0.53 \pm 3.97$ & 0 & 9 & \multirow{2}{*}{0.001} \\
\cline { 1 - 5 } Wonosari & 19 & $3.63 \pm 2.891$ & $2.24 \pm 5.02$ & -2 & 9 & \\
\hline Kasihan & 12 & $6.58 \pm 1.730$ & $5.48 \pm 7.68$ & 3 & 9 & \\
\hline
\end{tabular}

Source: primary data

TABLE 5 shows the difference scores of KOS on health workers in 3 primary health centers which remain, up, and down. There were no significant differences in scores KOS of health workers in 3 primary health centers that remain, up, and down $(\mathrm{p}=0.053)$.

TABLE 5. The difference scores of Knowledge of Schizophrenia

(KOS) on health workers in 3 primary health centers which remain, up, and down

\begin{tabular}{lccc}
\hline \multirow{2}{*}{$\begin{array}{c}\text { Primary Health } \\
\text { Center }\end{array}$} & \multicolumn{3}{c}{ KOS (Pretest \& Posttest) } \\
\cline { 2 - 3 } & Down/Remain & Up & $\mathrm{p}$ \\
\hline Dlingo 1 & $4(33.3 \%)$ & $8(66.7 \%)$ & \\
\hline Wonosari 2 & $2(10.5 \%)$ & $17(89.5 \%)$ & 0.053 \\
\cline { 1 - 3 } Kasihan 2 & 0 & $12(100.0 \%)$ & \\
\hline
\end{tabular}

Source: primary data

\section{DISCUSSION}

There were 12 health workers in Kasihan, 2 primary health center, 12 health workers in Dlingo 1 primary health center and 19 health workers in Wonosari 2 primary health center, and a total of 43 health care workers who completed the full training. The health workers are mostly nurses, as many as 17 people, followed by 8 midwives, 7 doctors and other health workers. Knowledge of Schizophrenia (KOS) at pretest in each health center showed that there was not any significant difference on pretest or the baseline $(p=0.162)$. The post test showed there was significant difference $(p=0.003)$ in the KOS's score. Psychoeducation is defined as the process of increasing the knowledge and change behavior for better in interacting with patients.17,18 Psychoeducation training about schizophrenia for the health workers was intended to provide psychoeducation for caregiver with psychotic disorders patients using brief interactive psychoeducation module about schizophrenia. This study showed that there was a significantly difference between pretest and posttest on health workers in 3 primary health centers. Average increase in 
Carla R. Marchira et al., Evaluation of primary health workers training program to provide psychoeducation to family caregivers of persons with psychotic disorder

knowledge of schizophrenia on health workers in 3 primary health centers is $23.09 \%$.

In this study there was significant differences between the mean delta KOS of health workers in 3 primary health centers $(p=0.001)$. This suggests that increased KOS at health workers in 3 primary health centers are not the same. Previous studies have shown if mental health services and mental training before exposure to psychoeducation training conducted at 3 primary health centers are not the same. Most likely this also affects the outcome of psychoeducation training. There were differences in scores of KOS in health workers who remain, up, and down at 3 Primary Health Centers. Dlingo 1 showed the increase in 8 health workers (66.7\%), Wonosari 2 showed the increase in 17 health workers $(89.5 \%)$, and Kasihan 2 showed the highest increase in 12 $(100.0 \%)$, however this difference was not statistically significant $(\mathrm{p}=0.053)$. Post-test showed more items of questions of Knowledge of Schizophrenia was answered correctly by health workers. Psychoeducation training make the knowledge of schizophrenia of health workers in 3 primary health centers increased.

\section{CONCLUSION}

The training program to provide psychoeducation to family care providers of persons with psychotic disorder for primary health workers was effective to increase their knowledge of schizophrenia.

\section{ACKNOWLEDGEMENTS}

This work was supported by USAID (Cooperative Agreement Number: AID497-A-11-00017), with project title: InterUniversity Partnerships for Strengthening Health Systems in Indonesia: Building New Capacity for Mental Health Care. This work was a cooperative agreement with USAID-
Indonesia to build inter-university partnerships between Harvard Medical School, Universitas Gadjah Mada (UGM), and Universitas Syiah Kuala (UnSyah).

\section{REFERENCES}

1. The World Bank. Global economic prospects and the developing countries. Washington DC: 1993.

2. Csernansky JG, Schuchart EK. Relapse and rehospitalisation rates in patients with schizophrenia: effects of second generation antipsychotics. CNS Drugs 2002; 16(7):473-84. http://dx.doi.org/10.2165/00023210-20021607000004

3. Taylor M, Chaudry I, Cross M, McDonald E, Miller P, Pilowsky L, et al. Towards consensus in the long-term management of relapse prevention in schizophrenia. Hum Psychopharmacol, 2005; 20(3):175-81. http://dx.doi.org/10.1002/hup.675

4. Sadock BJ, Sadock VA. (eds.), Kaplan and Sadock's Synopsis of Psychiatry, Behavioral Sciences/Clinical Psychiatry. London: Williams and Wilkins, 9th ed, 2003; 471-504.

5. Cardoso CS, Caiaffa WT, Bandeira M, Siqueira AL, Abreu MN, Fonseca JO. Factors associated with low quality of life in schizophrenia. Cad Saúde Pública 2005; 21(5):1338-40. http://dx.doi.org/10.1590/S0102311X2005000500005

6. Kohn R, Saxena S, Levav I, Saraceno B. The treatment gap in mental health care. Bull World Health Organ 2004; 82(11):858-66.

7. Sudiyanto, A,. Hambatan terapi pasien skizofrenia dan penyelesaiannya ditinjau dari sudut pandang pasien dan keluarga. Jiwa, Majalah Psikiatri, 2009; tahun XLII, No. 1:73-84.

8. Fortinash KM, Worret PAH. Psychiatric Mental Health Nursing, 4th Ed. St Louis: Mosby, 2007

9. Stuart GW, Laraia MT. Principles and practice of psychiatric. Nursing, 8th ed. St Louis: Elsevier Mosby, 2005

10. Marchira CR. Integrasi kesehatan jiwa pada pelayanan primer di Indonesia: Sebuah tantangan di masa sekarang. Jurnal Manajemen Pelayanan Kesehatan 2011; 14(3).

11. Marchira CR. Primary care health provider training on mental health. Paper Presented on 
Seminar on Strengthening Mental Health System In Indonesia. Yogyakarta, Indonesia: Psychology Faculty, Universitas Gadjah Mada, September 2014; 8-9.

12. Marchira CR. Psychoeducation intervention for schizophrenia in primary care in Jogjakarta, Indonesia. Paper presented for Workhop for Community Mental Health in Developing Countries. Taichung, Taiwan: 29 Oct-3 November 2014.

13. Arikunto S. Produser Penelitian: Suatu Pendekatan Praktik. Edisi Revisi. Jakarta: PT Rineka Cipta, 1998.

14. Marchira CR. Empowering relatives to reduce the stigma of psychotic illness: Year I, instrument validation and subject profile. Paper Presented for Schizophrenia Congress VI. Jakarta: 14-16 October 2010.

15. Marchira CR. The effectiveness of brief interactive psychoeducation intervention of schizophrenia towards the knowledge of caregivers, contact, compliance, and relapse of early psychosis in Jogjakarta.[Thesis].Yogyakarta: Medical Faculty, Universitas Gadjah Mada, 2012.

16. Compton MT, Quintero L, Esterberg ML.Assessing knowledge of schizophrenia: development and psychometric properties of a brief, multiple choice knowledge test for use across various samples. Psychiatry Res 2007; 151(1-2):87-95. http://dx.doi.org/10.1016/j.psychres.2006.05.019

17. Scottish Intercollagiate Guidelines Network (SIGN) Psychosocial Intervensions in The Management of Schizophrenia. Edinburgh: Royal College of Physicians, 1998.

18. Varghese M, Shah A, Kumar U, Murali T, Paul IM. Family intervention and support in schizophrenia. a manual on family intervention for the mental health professional. national institute of mental health and neurosciences. Bangalore:2002. 